\title{
ZNF700 Gene
}

National Cancer Institute

\section{Source}

National Cancer Institute. ZNF700 Gene. NCI Thesaurus. Code C101463.

This gene plays a role in the regulation of transcription. 